\title{
Essay \\ RIGHTS OF PASSAGE: MAJORITY RULE IN CONGRESS
}

\author{
JED RUBENFELD ${ }^{\dagger}$
}

\section{INTRODUCTION}

The United States government is a government not of rigorously separated powers, but of overlapping and concurrent powers: a government of checked and balanced powers. ${ }^{1}$ What strikes the balance? A few spare words of the Constitution. This is why the efforts of one body of government to alter the long-established understanding of those words are taken so seriously. In a complex structure, small changes in one body's movements can result in systemic shifts.

A case in point imvolves House Rule XXI(5)(c), adopted by the House of Representatives in January 1995.' Under this rule, no bill proposing to raise federal income taxes "shall be considered as passed" by the House without a three-fifths approving vote. ${ }^{3}$ This "three-fifths rule" marks the first time in history that the House has purported to alter the number of votes required to make a bill law.

Last year, seventeen law professors published an Open Letter (of which I was a signatory, but not an author) opining that the three-fifths rule is unconstitutional. ${ }^{4}$ A recent essay by Professors

$\dagger$ Professor of Law, Yale University. My thanks to William Van Alstyne, Akhil Amar, and Brian Sleigh.

1. See Mistretta v. United States, 488 U.S. 361, 381 (1989) ("In adopting this flexible understanding of separation of powers, we simply have recognized Madison's teaching that the greatest security against tyranny-the accumulation of excessive authority in a single Branch-lies not in a hermetic division anong the Branches, but in a carefully crafted system of checked and balanced power ....").

2. See RULES OF THE House OF REPRESENTATIVES (104th Cong.), Rule XXI(5)(c), reprinted in 141 CONG. REC. H23 (daily ed. Jan. 5, 1995).

3. See id. ("No bill . . . carrying a Federal income tax rate increase shall be considered as passed ... unless so determined by a vote of not less than three-fifths of the Members voting.").

4. See An Open Letter to Congressman Gingrich, 104 YALE L.J. 1539 (1995) [hereinafter Open Letter] (signed by Bruce Ackerman and sixteen others). 
John McGinnis and Michael Rappaport criticizes the Open Letter. ${ }^{5}$ This Essay is not so much a response to their criticisms (some of which are well taken) as an attempt to move the debate beyond its current position. The three-fifths rule, narrowly tailored though it may seem, raises profound constitutional issues that the commentary so far has not grasped.

\section{PASSING}

The constitutionality of the three-fifths rule boils down to the meaning of a single word in the Constitution: the word "passed," as it appears im the first clause of Article I, Section 7. Section 7 sets out the process by which Congress is to make law. The process is simple, and every student of American government knows it well. Every "Bill which shall have passed the House of Representatives and the Senate" must "be presented to the President." 6 The President has ten days to veto the bill. If he does not veto it, the bill becomes law. ${ }^{7}$ If he does veto it, Congress can override the veto, but only by a two-thirds vote in both the House and Senate. ${ }^{8}$

The language of Section 7 is mandatory. Any bill that "shall have passed" the House and Senate "shall . . . be presented" to the President and "shall become a Law" unless vetoed." The only question is how to construe the word "passed." If "passed" means "passed by whatever number of votes each house shall deem appropriate," then the three-fifths rule is constitutional. If "passed" is properly understood to mean "passed by majority vote," then the three-fifths rule is unconstitutional. The issue is that simple.

Professors McGinnis and Rappaport take the former position, arguing that "the Constitution permits each house to decide how many meinbers are necessary to pass a bill."10 Each house is said to have this power under Article I, Section 5, which authorizes each chamber to determine the rules of its proceedings. ${ }^{11}$ This

5. See John O. McGinnis \& Michael B. Rappaport, The Constitutionality of Legislative Supermajority Requirements: A Defense, 105 YALE L.J. 483 (1995).

6. U.S. CONST. art. I, $\S 7, \mathrm{cl} .2$.

7. This is so whether he signs the bill or not. See id. The Constitution makes an exception in the event that the ten-day period ends after Congress has adjoumed. See id.

8. See id.

9. Id. (emphasis added).

10. McGinnis \& Rappaport, supra note 5 , at 486 .

11. U.S. CoNST. art. I, $\$ 5$, cl. 2 ("Each House may determine the Rules of its 
interpretation of "passed"-reading it as a place-holder for the internal voting rules each house of Congress chooses to adopt-is obligatory if the three-fifths rule is to be defended. But it is a misguided interpretation, and deeply so.

\section{A. The Centrality of Majority Rule to Democracy}

Opponents of the three-fifths rule have einphasized the centrality of majority rule to deinocracy itself. ${ }^{12}$ They lave cited authority, especially from our own founding era, which suggests that the right of a majority to change the law is central to democratic legitimacy and essential to the health of democratic nations. ${ }^{13}$ In reply, defenders of the three-fifths rule point to "[b]icameralism" and "the separation of powers" as counter-examples to the rule of majority rule (at least of popular majority rule). ${ }^{14}$ They assert that supermajority requirements can further "the cause of democratic self-governance" by assuring that important decisions are made only when strongly supported by a wide range of "the electorate as a whole."15 They also defend the three-fifths rule as a wise constraimt on the propensity of legislatures toward fiscal irresponsibility. ${ }^{16}$

All of these arguments are beside the point. Majority rule is not an invariable requirement of democracy. Constitutionalism itself, not bicameralism or the separation of powers, is the proper counter-example. Nor does it make a difference whether the threefifths rule is sound fiscal pohicy or an impediment to Congress's ability to respond to changing circumstances. (I have no idea

Proceedings .....").

12. See Open Letter, supra note 4, at 1539 (stating that the three-fifths rule contributes to "erosion of our central constitutional commitments to majority rule and deliberative democracy"); Benjamin Lieber \& Patrick Brown, Note, On Supermajorities and the Constitution, 83 GEO. L.J. 2347, 2350-51 (1995).

13. The Open Letter cites a passage from The Federalist in which Madison responds to a suggestion that the Constitution should have required a supermajority vote of Congress for the passage of at least some, if not all, legislation:

In all cases where justice or the general good might require new laws to be passed, or active measures to be pursued, the fundamental principle of free government would be reversed. It would be no longer the majority that would rule; the power would be transferred to the minority.

Id. at 1540 (quoting THE FEDERALIST No. 58, at 397 (James Madison) (Jacob E. Cooke ed., 1961)).

14. See McGinnis \& Rappaport, supra note 5, at 508.

15. Id. at $508,509$.

16. See id. at 509-10. 
which it is, if either.) The question is not whether the three-fifths rule is the most politic policy or whether it would exist in the most democratic democracy. The question is whether it is constitutional.

\section{B. Arguments from Silence and Original Intent}

On the question of constitutionality, much of the debate so far has emphasized arguments from constitutional silence and original intent. The Constitution contains several provisions im which supermajority votes in the House or Senate are specifically required (such as the two-thirds vote required after a presidential veto). But the Constitution apphes no such requirement to the initial passage of bills by the House or Senate (before presentment to the President). Froin this silence, one can draw clear, plausible inferences about the Framers' intent. The only difficulty is that one can draw two different inferences.

The argument against the three-fiftlis bill is that the Framers knew how to call for supermajority votes when they wanted to, so the absence of a supermajority provision covering the initial passage of legislation means that majority rule was intended. ${ }^{17}$ The reply is that, on the contrary, the Framers knew how to call for a specific number of votes when they wanted to, so the fact that there is no express numerical requirenent concerning the initial passage of legislation means that no particnlar number of votes was required. ${ }^{18}$

The truth is that the argument from silence is not dispositive. The same is true of the effort to establish the meaning of "passed" on the basis of historical sources such as The Federalist, notes from the Philadelphia Convention, and so on. These sources contam numerous statements supporting majority rule in the House and Senate, but arguably only with the intention that the

17. See Open Letter, supra note 4, at 1541 ("On seven different occasions, [the Constitution] stipulates a supermajority requirement. ... [But] it never places any special obstacles in the way of the enactment of ordinary legislation signed by the President."); see also Neals-Erik William Delker, The House Three-Fifths Tax Rule: Majority Rule, the Framers' Intent, and the Judiciary's Role, 100 Dick. L. REV. 341, 348-50 (1996) (arguing that "the Framers were careful to himit the use of supermajority requirements to a few special cases").

18. See McGinnis \& Rappaport, supra note 5, at 486 ("The Constitution's silence on the number necessary to pass a bill stands in stark contrast to other provisions that specify the requisite number to undertake particular actions."). 
House and Senate be permitted to pass legislation by majority vote, not that they be required to do so. ${ }^{19}$

Would the Framers have said that each house's rules-of-proceedings authority included the power to define what it means for a bill to "pass" under Article I, Section 7? Or when they said "rules of proceedings," did they mean to embrace only sub-constitutional procedural rules such as parliamentary rules, rules of order, committee rules, and so on? Let's put aside what the Framers meant to be saying and consider instead what they committed to writing.

\section{The Plain Meaning of the Text}

The case against the three-fifths rule can be made on the basis of the plam meaning of the constitutional text, which I shall take to mean the meaning that would have been plain to those who wrote and ratified the Constitution.

When someone wants to know the outcome of a majority vote in a legislative body, ordinary Enghish usage asks whether the measure "passed."20 Dictionaries of older American and Enghish legal usage define "pass" in just such terms: "When a legislative bill is finally assented to by a majority vote of the body . . . it is said to be 'passed' by such body ...."21 Majority rule was, moreover, the established practice of the British Parhiament and was regarded as the "natural" rule for all assemblies. ${ }^{22}$ Thus, at least where no contrary rule was specified, those who ratified the Constitution would certainly have understood "passed" to mean "passed by majority vote."

19. Compare Open Letter, supra note 4, at 1540 (citing critiques in The Federalist as evidence that the Framers intentionally rejected "supermajority rule for especially sensitive legislation") with McGinnis \& Rappaport, supra note 6, at 490-91 (distinguishing same).

20. Indeed, the majority-rule understanding of "passed" is so conventional that it is sometimes treated as part of that term's express meaning, rather than as a mere implication. Thus the Supreme Court has referred to "passage by a majority of both Houses" as part of "the express procedures of the Constitution's prescription for legislative action." INS v. Chadha, 462 U.S. 919, 958 (1983) (emphasis added).

21. 2 STEWART RAPALJE \& ROBERT E. LAWRENCE, A DICTIONARY OF AMERICAN AND ENGLISH LAW 935 \& 4 (1888).

22. See, e.g., THOMAS JEFFERSON, Notes on the State of Virginia, in 2 THE WRITngs OF THOMAS JEFFERSON 1, 172 (1905); THOMAS JEFFERSON, A Manual of Parliamentary Practice $\S \mathrm{XLI}$, in 2 THE WRITINGS OF THOMAS JEFFERSON supra, at 335, 420-21. 
Unfortunately, the case for the three-fifths rule can also be made on the basis of the plain meaning of the text. To pass, im the legislative context, means no more than to secure the number of favorable votes necessary for an affirmative outcome, whatever that number of votes happens to be. This understanding was as current in 1789 as it is today; eighteenth-century dictionaries confirm this usage, ${ }^{23}$ and indeed the Constitution itself uses "pass" im just this sense later im Article I, Section 7, when it provides that Congress can "pass" a vetoed bill by a two-thirds vote in both channbers. ${ }^{24}$ Thus, the proper meaning of "passed" in Article I, Section 7 is "approved by whatever number of votes, or whatever kind of vote, is called for in the operative rules of proceedings," and those who ratified the Constitution would clearly have so understood it.

When we face a problein of constitutional interpretation, it is always tempting to look to another source to resolve it: a definitive statement in the legislative history, a view espoused by a revered authority, a definition in a dictionary. At the end of the day, however, those whoin we charge with imterpreting what this nation committed to writing 200 years ago will find no authoritative answer waiting for them $m$ any extrinsic source. Which is only to say that those whom we charge with interpreting the Constitution must-interpret the Constitution.

\section{The Proper InTERPRetation of ARTiCle I, Section 7}

And the proper interpretation of Article I, Section 7, is that "passed by the House" means passed by inajority vote of the House.

Section 7 contains the Constitution's Lawmaking Clauses. It is therefore one of the most central provisions-maybe the central provision-of the entire Constitution as originally written. A constitution is defined as a constitution in large part by the fact that it provides a nation with rules of recognition for all other laws. A constitution lays down the process by which law is to be made and recognized, identifying the various governmental actors whose

23. See Thomas Sherddan, A COMplete Dictionary of tHe ENGlish LaNGUAGE (6th ed. 1796) (defining "pass" as "to enact a law").

24. See U.S. CONST. art. I, $\S 7$, cl. 2 ("If after such Reconsideration two thirds of that House shall agree to pass the Bill ...."). 
concurrence must be obtained when the awesome power to make law for a nation is exercised.

The Lawmaking Clauses, and the questions they would answer, were of critical importance to those who made the Constitution. Nearly nothing was more important to them, for exainple, than the question of how much influence the various states would have in the passage of law, or what role the President would play in legislating. ${ }^{25}$ These and other equally crucial questions were decided by: 1) the "great compromise" that determined the different compositions of the House and Senate; and 2) the Lawmaking Clauses of Article I, Section 7. Deceptively smiple on their surface, the Lawmaking Clauses in fact embody "a single, finely wrought and exhaustively considered, procedure" for lawmaking im which the great structural questions facing those who made our Constitution were resolved. ${ }^{26}$

Section 7 strikes a balance between large and small states, between state and federal government, between House and Senate, between Congress and President. This balance of powers would be entirely undone if it were true that each legislative chamber could define what it means for that chainber to "pass" a bill. The following exainples will make this clear.

In January 1997, led by the Representatives from California, Texas, and New York, the delegates from the ten largest states meet early in the Capitol and convene the first session of the House of Representatives of the 105th Congress. ${ }^{27}$ They pass the "Big-Ten Rule," which states that a bill shall be deemed to have passed the House if and only if it has secured a three-fifths vote of the delegates of these states.

In January 1999, the House repeals the Big-Ten Rule and passes in its stead the "Big-Three Rule." This House rule states that a bill shall be deemed to pass according to traditional rules of majority rule, except that in determining whether a bill has secured a majority of the House, any votes cast by Representatives of California, New York and Texas shall not be counted either in the numerator or the denominator.

25. A brief discussion of this history can be found in Chadha, 462 U.S. at 946-51.

26. Chadha, 462 U.S. at 951.

27. They can do so because, together, they are sufficient to form a quorum. See U.S. CONST. art. I, $\S 5$, cl. 1 . It is interesting to observe that the constitutional quorum requirement is fixed as a "[m]ajority." Id. 
The Big-Ten and Big-Three Rules exercise the precise power claimed by supporters of the three-fifths rule: the power of each house to decide how many members are necessary to pass a bill. But the Big-Ten Rule is a sort of coup d'etat, and the Big-Three Rule is an ouster. Surely alterations of this magnitude in the constitutional allocation of powers among the states cannot be permitted in the form of House "Rules of Proceedings."

It will be said, I expect, that these two hypothetical rules are completely distinguishable from the three-fifths rule. The Big-Ten and Big-Three Rules deprive certain Representatives and certain states of their votes altogether. Obviously, it might be said, a House rule violating an mdependent requirement such as "oneRepresentative-one-vote" is unconstitutional. But where is this "independent requirement" provided for? There is no provision in the Constitution expressly declaring that each Representative shall have one vote, and that each vote will be counted equally. This is not to say that there is no one-Representative-one-vote requirement in the Constitution. On the contrary, there is such a requirement, but it follows from the majority-rule reading of Article I, Section 7 itself.

A well-known feature of simple majority-rule voting regimes-not merely as a matter of practice, but as a matter of definition-is that each individual in the decisionmaking body gets one equal vote. ${ }^{28}$ It is of course possible to construct more complex voting schemes, but a snnple majority vote within a legislative body has always ineant a vote of one-half-plus-one, with each legislator accorded one equal vote. The one-Representative-onevote principle central to our national lawmaking process is constitutionally required precisely because "passed the House" means "passed by majority vote of the House.".29

To be sure, the three-fifths rule also contemplates each Representative having exactly one vote. But the interpretation of

28. See, e.g., Kenneth O. May, A Set of Independent Necessary and Sufficient Conditions for Simple Majority Decision, 20 ECONOMETRICA 680, 681-82 (1952) (listing as one necessary condition for sinple majority decision that "each individual be treated the same as far as his imfluence on the outcome is concerned").

29. This does not mean a majority vote of all the Representatives, just as it does not mean a majority vote of three Representatives. It means a majority vote of the House, which is to say, a majority vote taken when a sufficient number of Representatives are present to make a quorum allowing the House to act. On the Constitution's quorum provision, see supra note 27. 
"passed" underlying the three-fifths rule does not demand this result. To support the three-fifths rule is not to say that "passed" means "passed by a three-fifths vote of the House." It is to say that "passed" means "passed by whatever number of votes is called for in the relevant House rules." It is to say, in other words, that "passed" has no independent meaning, but is rather to be defined by the House through its rules of proceedings. So defined, "passed" cannot be said to require a one-Representativeone-vote principle: the House could adopt cumulative voting, different states could be allotted greater or lesser numbers of votes than their number of Representatives, or different Representatives' votes could be weighted differently. The three-fifths rule may happen to honor the one-Representative-one-vote principle, but the interpretation of "passed" on which it rests is perfectly consistent with that principle's abrogation.

Supporters of the three-fifths rule have only two possible rephes. First, they can embrace the consequences of their logic and say that the Big-Ten and Big-Three Rules are indeed constitutional. If so, then they have made the case against their own position, for surely it is a fatal argument against a proposed reading of Article I that it permits states to be deprived of their votes in Congress, or that it allows a few states to seize control of the legislative powers of the nation. ${ }^{30}$

Second, supporters of the three-fifths rule can concede the validity of the one-Representative-one-vote principle, but claim to derive this principle from some source other than Article I, Section 7. In this way, they could still oppose the Big-Ten and BigThree Rules without abandoning the three-fifths rule. But where else in the Constitution is the one-Representative-one-vote requirement to be found? Because no other clause of the Constitution expressly or implicitly calls for a one-Representative-one-vote prin-

30. The only time in the nation's history that something of this sort occurred was in the 1860 s, when a majority of the 39 th Congress refused to seat the putative representatives from the Southern states. This precedent in no way supports the proposition that a state's Representatives inay be wholly disenfranchised by House rule. Even on the assumption that the rebellious Southern states were still 'states' at that time, entitled to representation in Congress, the position of the 39th Congress was not that a majority of either chamber had the power to disenfranchise states as it saw fit, but rather that, in the exceptional circumstances of the time, the Southern states could not be represented in Congress until their electoral processes had been reconstructed in such a way as to assure that the suffrage had been extended to blacks and union loyalists. See generally BRUCE ACKERMAN, We the PEOPLE: TRANSFORMATIONS chs. 3-6 (forthcoming 1997). 
ciple, they will have to paint that principle as some sort of constitutional omnipresence, derivable from the penumbras and emanations of other provisions. In fact, not only is there no provision expressly stating that each Representative gets one vote, but there is a provision expressly stating that each Senator gets "one Vote." ${ }^{31}$ Thus, by the sort of power-from-silence argument that the supporters of the three-fifths rule endorse, it should follow that the Constitution does not require each Representative to have one equal vote. In other words, on the theory underlying the three-fifths rule, the House should be able to give different Representatives different numbers of votes through a duly enacted House rule.

A majority-rule reading of "pássed" involves no such dubieties. This reading makes sense of Section 7 as a whole (given the two-thirds-override provision that follows), conforms with historical practices, and explains other provisions of the Constitution..$^{32}$ In other words, the one-Representative-one-vote principle can be conjured up through penumbras, emanations, structures, and unexpressed intentions, or it can be recognized in the implicit but precise and perfectly straightforward definition of the word "passed." A bill that has "passed the House of Representatives" is a bill that has passed by a majority vote of the House of Representatives.

Another exainple dictates the saine conclusion. Suppose that the House adopts a rule stating that all bills affecting the District of Columbia shall be deemed to have "passed the House" only if approved by the Mayor of the District. Everyone, I hope, will agree that this "D.C. Rule" is unconstitutional; hoine rule cannot be accomphished by House rule. But if the D.C. Rule is unconstitutional, then there exists another requirement pertaining to the passage of bills by Congress: a requirement that only the votes of Representatives and Senators count. Where is this requirement expressed in the Constitution?

It is expressed, once again, in the word "passed," understood as passed by majority vote. The D.C. Rnle is unconstitutional because every bill that has passed by a majority vote of the House of Representatives and the Senate must be presented to the Presi-

31. U.S. CONST. art. I, § 3, cl. 1.

32. For example, the Vice President is given the power to vote in the Senate in case the Senators are "equally divided." U.S. CONST. art. I, $\S 3, \mathrm{cl}$. 4. 
dent and, absent a veto, shall be the law of the land-irrespective of anyone else's approval. What it means for a bill to "pass" the House or Senate is not open for definition by the House or Senate. It is constitutionally fixed by the implicit majority-rule meaning of "passed." Unmoored from this meaning, the Lawmaking Clauses would in no way stand against the D.C. Rule or any other House rule attempting to give some extra-congressional figure a vote or veto in national legislation.

Once again, to distinguish the D.C. Rule, a supporter of the three-fifths rule would have to look elsewhere in the Constitution than Article I, Section 7. There are, however, very few places to look. Some other clause would have to be manipulated to produce the only-Representatives-may-vote result. ${ }^{33}$ Even if this manipulation were possible, a far more straightforward solution is available: the votes of persons other than Representatives or Senators do not count toward making a bill law because the Lawmaking Clauses already specify whose votes count. They do so by declaring that any bill passed by a majority vote of both houses shall be a law regardless of the approval or disapproval of anyone else $i m$ the world, except of course the President.

Consider next a House rule requiring a nime-tenths vote for all bills to "pass." ${ }^{.34}$ Besides making it extremely difficult for any

\section{Professors McGinnis and Rappaport suggest, for example, that:}

[T] he House ... could not use the authority of the Rules of Proceedings Clause to adopt a rule permitting individuals other than members ... to vote on legislation, because such a rule would violate the provision of Article I, Section 2, Clause 1 that states that '[t]he House of Representatives shall be composed of Members [elected every second Year by the People of the several States]."

McGinnis \& Rappaport, supra note 5, at 485 n.9. It is something of a stretch to extract the only-Representatives-may-vote principle from a clause whose obvious purpose is to specify the length of Representatives' terms and their popular election. Such an interpretation of Section 2 is not impossible, but one who adopts it is manifestly using the onlyRepresentatives-may-vote principle to drive the interpretation of "composed" or "Members." Thus, even if this interpretation of Section 2 is permissible, see, e.g., Michel v. Anderson, 14 F.3d 623, 630 (D.C. Cir. 1994) (adopting this reading of Section 2), why shouldn't the same primciple inform the interpretation of Section 7? Section 7 is far more naturally read (through the majority-vote reading of "passed") to reach the only-Representatives-may-vote conclusion, which Section 2 must be strained to yield.

In any event, if the House really has the authority to define the rules under which a bill has "passed" for Section 7 purposes (a power not asserted in the Michel case), it is unclear why the House could not deem a bill to have passed ouly if it had been approved by someone other than a member of the House. The House would not be saying that the Mayor of the District was a "Member" of the House, merely that his approval of legislation was necessary before a bill would be deemed to have "passed."

34. Professors McGinnis and Rappaport seem to concede that if the House can re- 
bill to becoine law, a "90\% rule" would give California, acting alone, the power to veto any bill that had in fact passed by a majority vote of the House. At the same time, a $90 \%$ rule would give small states a much greater degree of control over the legislative process than they currently enjoy. Can such fundamental changes in the constitutional balance of powers be left to the discretion of each legislative chamber through its "rules of proceedings"?

Fimally, consider a House Rule of the following form: "A bill shall be deemed to have 'passed' the House if it secures a twothirds vote, provided that an identical bill also secures a two-thirds vote of the Senate; but if a bill does not secure a two-thirds vote of the Senate, then the same bill shall be deemed not to have passed the House in any circumstance." Call this the "two-thirdstwo-thirds rule," because its consequence is that federal law can be inade only upon a two-thirds vote of both legislative chambers. Isn't it clear that such a rule fundamentally alters the structure of the lawnaking process established by Article I, Section 7? Under Section 7, our lawmaking process is a two-tiered process in which the presidential veto plays a pivotal role. Article I demands a special supermajority vote in both the House and Senate if law is to be made without the President's concurrence. The two-thirdstwo-thirds rule transforms this process into one in which law can only be made upon that very same bicameral supermajority vote, rendering the President's concurrence a virtual forinahty. The constitutional structure of lawmaking lias been fundamentally altered, soinething a mere House rule cannot be permitted to do.

One might argue that the two-thirds-two-thirds rule is different from the three-fifths rule because it conditions the requisite number of House votes on action taken in the Senate. It is clearly permissible, however, for ordinary rules of proceedings in one chamber to be conditioned on activity taken in the other. Such rules are common, as when the House or Senate adopts conference rules conditioned on the participation of the other chamber. If the two-thirds-two-thirds rule is different, it is different only in that it: 1) einploys a senatorial condition to increase beyond a simple majority the number of House votes necessary for a bill to "pass" the House; or 2) involves a senatorial condition increasing

quire a three-fifths vote to pass a bill, "there is no principled reason why it could not also require a $99 \%$ vote." McGinnis \& Rappaport, supra note 5, at 504. 
beyond a simple majority the number of Senate votes necessary for a bill to "pass" the Senate. In other words, the two-thirds-twothirds rule is unconstitutional precisely because Article I, Section 7 , is properly read to provide that every bill which shall have passed the House and Senate by majority vote shall, with the President's concurrence, become law.

A vast, complex constitutional balance of powers-the powers of states as against territories, the powers of each state as against other states, the powers of large states as agamst small states, the powers of the House, Senate, and President as against each other-is attained and embodied in the spare words of Article I, Section 7. It strikes this balance by providing for a two-tiered structure of lawmaking. Every bill passed by a majority vote of the House and Senate "shall become a Law," unless the President exercises his veto power. If the President vetoes the bill, then and only then must a bill be passed by a supermajority of the House and Senate in order to become law. This reading of "passed" provides a fully sufficient ground for supporting the following principles: 1) every Senator and Representative gets one equal vote;

2) only the votes of Senators and Representatives count; 3) the relative voting power of the small and large states to pass law cannot be changed; 4) no state can be given the power to veto legislation passed by a majority vote of the chamber; and 5) neither chamber can transform the legislative process from a twotiered process with a decisive presidential veto, into a two-thirdstwo-thirds process in which the President's veto is a virtual formality. Absent this reading, the validity of every one of these primciples becomes suspect. Every one of them, if it can find a purchase at all, must cast about for other grounds, looking for security in penumbras, emanations, and structural implications.

\section{THE INFINITE REGRESS}

We have thus far reflected on the importance of the majorityrule reading of "passed" to the mamtenance of various core ingredients of the careful balance of powers that Article I, Section 7 establishes for the federal government. But there is also a matter of logic to consider. Whenever a court construes an organic legal document that establishes a legislative body without specifying the voting rule applicable to the initial passage of legislation by that body, the court must, as a matter of logic alone, infer some de- 
fault rule. For if the legislative body sought to legislate voting rules for itself, it would first have to decide how many votes would be necessary, and how to count the votes cast, in the vote taken to decide the voting rules. To settle that meta-voting-rule, it would need a meta-meta-voting-rule. And so on.

Thus, a default rule of one sort or another is indispensable, and for a variety of excellent reasons, a court might read majority rule into the organic document as the correct default rule. Under majority rule, no legislator is preferred over any other and no outcome is preferred over any other. Moreover, majority rule is simple to administer; it can be said to reflect the "will of the body" in some sense; and it has been the near-universal historical practice of Anglo-American legislative bodies. For such reasons, courts have long held that majority rule is the default rule for a legislative body when the organic document does not specify otherwise. ${ }^{35}$ In fact, the Supreme Court of the United States, interpreting Article I, Section 7, once so stated:

[T] he general rule of all parliamentary bodies is that, when a quorum is present, the act of a majority of the quorum is the act of the body. This has been the rule for all time, except so far as in any given case the terms of the orgamic act under which the body is assembled have prescribed specific limitations. . . . No such limitation is found in the Federal Constitution, and therefore the general law of such bodies obtams. ${ }^{36}$

If this Essay were a legal brief, it would surely have begun with this quotation froin United States v. Ballin. Ballin is, however, an old case and did not involve an expressly contrary House or Senate Rule. The supporters of the three-fifths rule believe they can distinguish it, ${ }^{37}$ and in any event, we who read and write about the Constitution have the burdensome luxury of not being bound even by the Supreme Court. The point is that, based solely on the need to infer some default voting rule, there is excellent reason to read majority rule into Section 7 . Combined with the considerations advanced above, the case is overwhelming.

35. See, e.g., United States v. Ballin, 144 U.S. 1, 6 (1892); State v. Deliesseline, 12 S.C.L. (1 McCord) 52, 60 (1821); Rex v. Monday, 98 Eng. Rep. 1224, 1228-29 (K.B. 1777).

36. Ballin, 144 U.S. at 5.

37. See McGinnis \& Rappaport, supra note 5, at 492-93. 


\section{THE EFFECT OF ARTICLE I, SECTION 5}

Article I, Section 5 provides that each house "may determine" its own rules of proceedings. Observe that this clause contains not a word about the number of votes required to enact a rule of proceeding. The three-fifths rule was, however, adopted by majority rule. In other words, supporters of the three-fifths rule (or at least those in Congress) recognize a majority-rule default rule in the Constitution. ${ }^{38}$ They simply choose to recognize it with respect to the power of the House and Senate to make their own rules of proceedings, rather than with respect to the power of the House and Senate to make law. For supporters of the three-fifths rule, majority rule is to be read into Section 5 despite the Constitution's silence on the subject, whereas it must not be read into Section 7 because of the Constitution's silence on the subject. Thus, supporters of the three-fifths rule are domg with Section 5 what they protest against when it comes to Section 7 .

To be sure, reading a majority-rule default rule into Section 5 , rather than Section 7 , is not incoherent. It does not violate any considerations of formal logic. It is simply imisguided, violating every consideration of constitutional logic. Supporters of the threefifths rule want to take the clause that, naturally enough, confers upon each legislative chamber authority over its own parhiamentary proceedings and turn it into something more: a power within each chamber fundamentally to disrupt the basic structure of national lawmaking. Is it sensible to make the Constitution's Lawmaking Clauses subordinate, as a matter of constitutional logic and status, to its rules-of-proceedings clause? Is it sensible to do so at the cost of either giving up fundamental constitutional primciples (oneRepresentative-one-equal-vote, only the votes of Representatives count, and so on) or at least giving up the best and simplest grounds for these primciples?

To raise these questions, I beheve, is to see their answer. The House's authority over its own internal rules caimot be a power to alter the basic constitutional rules of recognition-the rules that define the Constitution as a constitution. To say otherwise would be to put the cart before the House.

Supporters of the three-fifths rule point to the Senate's filibus-

38. See McGinnis \& Rappaport, supra note 5, at 491 \& n.40. 
ter rule as a well-established rule of proceeding that also frustrates majority rule. ${ }^{39}$ But the filibuster rule does not purport to alter the Constitution's rules of recognition. Numerous committee rules can block a bill from coming to the floor even though the bill might or would have been passed (by majority vote) had it made its way to a vote. Wise or unwise, such rules do not alter the criteria by which the legal system determines whether an act is law. The argument here is not that any rule impeding majority rule in the House or Senate is unconstitutional. But a rule purportedly changing the rule of majority rule (for the passage of laws) is unconstitutional, because majority rule is the rule constitutionally laid down.

\section{THE REPEALABILITY of House Rules}

A final word needs to be said about the repealability of the three-fifths rule. Supporters of the three-fifths rule claim that the rule doesn't really overturn majority rule in lawmaking because the House's current rules allow a fairly easy repeal or avoidance of the three-fifths rule upon a simple majority vote. ${ }^{40}$ Indeed, Professors McGinnis and Rappaport argue that any House rule purporting to make itself unrepealable by a majority vote of the House would be unconstitutional. ${ }^{41}$ Astomishingly, they support this assertion on the basis of the same arguments-unexpressed intentions, an nnwritten principle that a legislature cannot block at time one the functioning of majority rule at tinne two-that opponents of the three-fifths rule have been making all along. ${ }^{42}$

This portion of their argument makes Professors McGinnis and Rappaport vulnerable to a charge of self-contradiction, or at least to a charge of invoking on their own behalf the very rhetorical moves that they would disallow to their opponents. A partisan of the three-fifths rule, however, need not follow Professors McGinnis and Rappaport down this inajoritarian road. ${ }^{43}$ But if the partisan does not take the majoritarian position, then the issue of repealability becomes irrelevant.

\footnotetext{
39. See, e.g., id. at $496-97$.

40. See id. at 500-03.

41. See id. at 503-04.

42. See id. at 504-06.

43. It might be said, for example, that the House could properly make repeal of House rules impossible except upon a supermajority vote.
} 
If supporters of the three-fifths rule take the majoritarian position-that as a mere House rule, the three-fifths rule is essentially repealable or avoidable at will by majority vote-then they are saying that the three-fifths rule cannot block any bill from passing the House that would have passed by majority vote in the first place. In that case, the three-fifths rule is merely hortatory, and there is no real dispute. Everyone agrees, in effect, that the operative constitutional principle is that a bill must be permitted to pass the House by majority vote.

If, on the other hand, supporters of the three-fifths rule do not take the majoritarian position, they acknowledge that under some circumstances the three-fifths rule would in fact block a bill from passing even though a majority of those voting voted for it, i.e., even though the bill was in fact passed by majority vote. Which is only to say that, in some cases, the three-fifths rule would have a real effect. This consequence was surely the idea behind the rule, and it would appear to be quite possible under current House rules. ${ }^{44}$ If the three-fifths rule does have any real effect, however, then for all the reasons given above it is unconstitutional.

\section{CONCLUSION}

Constitutional grants of power have proven to be highly expandable. The executive branch today wields not only the executive powers specified in the Constitution, but also various legislative and judicial powers as well. In a system of rigorously separated powers, such expansion of powers would have been impermissible.

It is permissible in a system of checked and balanced powers, however, because the principal aim of such a systein is to protect

44. Professors McGinnis and Rappaport point out that current House rules permit the amendment of any standing rules upon a simple majority vote, and that they also permit "special rules" to be adopted for a given bill by simple majority vote. See McGinnis \& Rappaport, supra note 5, at 501-02. But the Professors also concede that such action normally can be taken only if the Rules Committee forwards the appropriate rule proposal to the floor. See id. If, therefore, Representatives favoring the three-fifths rule controlled the Rules Committee (a not unlikely scenario), it would be logical to expect that no such proposal would be forthcoming. Current House rules do provide for a petition to discharge a measure from a committee, but a discharge petition must be approved by an absolute majority of the entire House, not by a majority of a quorum. See RULES OF THE HOUSE OF REPRESENTATIVES, supra note 2, at House Rule XXVI(3). 
against "the accumulation of excessive authority in a single Branch," body or official ${ }^{45}$ - to provide "security against tyranny." ${ }^{.46}$ The great danger is unilateral power, and not every expansion of power poses that danger. On the contrary, an expansion of one branch's powers that creates an overlap or concurrence of powers with another branch can be an antidote to unilateral power. At the same time, and for the same reason, a diminution in the powers of one branch or body can in some cases pose a greater threat to a system of checked and balanced powers than an increase in powers would. Most of the expressly specified grants of power-the presidential veto, for example-cannot be subtracted from the system without taking away a very substantial check on another branch's powers.

The Constitution's grants of power cannot be diminished below their constitutional floor. But this contraction of a core constitutional power is just what the three-fifths rule purports to accomplish. Article I, Section 7, grants the Congress power to make law for the nation by majority vote, with only the President standing in the way. The three-fifths rule is in reahty the assertion of a power to contract this core power: it is an attempt by majority vote of the House to take away the power of Congress to make law by inajority vote. As a result, the three-fifths rule facilitates the accumulation of excessive authority by other players in the constitutional system. It inay not have been the intent of those who enacted the three-fifths rule, but the rule makes possible in principle the seizure of the lawmaking power by the ten largest states, the ouster of states from the lawmaking process, the vesting of a veto power over congressional law in someone outside the federal government, the vesting of a veto power in a single state, and so on. And it does all this through the unilateral action of a single legislative chamber.

The power to which the three-fifths rule lays claim is the power fundamentally to disrupt the constitutional balance of powers. Neither the House nor the Senate possesses such power, at least not when acting through the unilateral device of making rules of its own proceedings.

45. Mistretta v. United States, 488 U.S. 361, 381 (1989).

46. Id. 